\title{
Changes in the Numbers of Ribbon Synapses and Expression of RIBEYE in Salicylate-Induced Tinnitus
}

\author{
Feng-Ying Zhang a,b,c Yi-Xue Xue $e^{b, d}$ Wen-Jing Liu ${ }^{a}$ Yi-Long Yao \\ Jun Mab,d Lin Chen ${ }^{a}$ Xiu-Li Shang ${ }^{a}$
}

\begin{abstract}
aDepartment of Neurology, The First Affiliated Hospital, China Medical University, ${ }^{b}$ Department of Neurobiology, College of Basic Medicine, China Medical University, 'Department of Neurology, The First People's Hospital of Shenyang, 'Institute of Pathology and Pathophysiology, China Medical University, e'Department of Neurosurgery, Shengjing Hospital of China Medical University, Shenyang, People's Republic of China
\end{abstract}

\section{Key Words}

Salicylate $\bullet$ Inner hair cell $\bullet$ Ribbon synapse $\bullet$ Tinnitus $•$ RIBEYE

\begin{abstract}
Background: This study was performed to explore the mechanism underlying tinnitus by investigating the changes in the synaptic ribbons and RIBEYE expression in cochlear inner hair cells in salicylate-induced tinnitus. Methods: C57BL/6J mice were injected with salicylate (350 $\mathrm{mg} / \mathrm{kg}$ ) for 10 days and grouped. Behavioral procedures were performed to assess whether the animals experienced tinnitus. The specific presynaptic RIBEYE protein and non-specific postsynaptic glutamate receptor $2 \& 3$ protein in basilar membrane samples were examined by immunofluorescent labeling. RT-PCR and Western blot assays were used to examine RIBEYE expression. Serial sections were used to build three-dimensional models using $3 \mathrm{ds}$ MAX software to evaluate the changes in the synaptic ribbons. Results: The administration of salicylate increased false positives in the behavioral procedure from $3 \mathrm{~d}$ to $10 \mathrm{~d}$. The membrane profiles of inner hair cells in all mice were intact. The number of synaptic ribbons in the salicylate group increased on the $7^{\text {th }} \mathrm{d}$ and decreased on the $9^{\text {th }}$ and $10^{\text {th }} \mathrm{d}$. mRNA and protein expression of RIBEYE were initially up-regulated and later down-regulated by injecting salicylate for 10 consecutive days. Conclusion: This change in the ribbon synapses of cochlear inner hair cells in salicylate-induced mice might serve as a compensatory mechanism in the early stages of ototoxicity and contribute to tinnitus later. The alteration of RIBEYE expression could be responsible for the changes in the morphology of ribbon synapses and for salicylateinduced tinnitus.
\end{abstract}

F.Y. Zhang and Y.X. Xue contributed to this work equally. 


\section{Cellular Physiology and Biochemistry}

Cell Physiol Biochem 2014;34:753-767

DOI: $10.1159 / 000363040$

Publisned online: August 19, 2014

C 2014 S. Karger AG, Basel

www.karger.com/cpb

754

Zhang et al.: Ribbon Synaptic Number and RIBEYE Expression in Tinnitus

\section{Introduction}

Tinnitus, described as a type of phantom sound (ringing of the ears), is a subjective perception of sound in the absence of corresponding external sources [1]. Tinnitus is a common symptom of hearing impairment that affects millions of people worldwide [2, 3]. There is no effective therapy for it at this time, and the related biological molecular mechanism remains unclear. For example, the pathological changes and signaling pathways involved in the development of tinnitus are still under debate. It is undoubtedly necessary to clarify the biological changes and molecular mechanisms to develop effective therapies for tinnitus. However, basic studies of tinnitus are still insufficient and are difficult to perform. This is due, in part, to the difficulty in inducing and measuring tinnitus in animal experiments. Natriumsalicylicum (salicylate), the active component of aspirin, is widely used for its antipyretic, analgesic and anti-inflammatory effects. It has been revealed that salicylate can induce reversible tinnitus in both humans and animals [4-11]. Therefore, salicylate is commonly utilized to induce tinnitus in animal models for studies of tinnitus, and salicylateinduced tinnitus could be detected by the conditioned suppression/avoidance procedure [11]. However, the mechanisms of salicylate-induced tinnitus are still controversial and uncertain. Jung et al reported that salicylate ototoxicity is associated with decreased levels of vasodilating prostaglandins and increased vasoconstricting leukotrienes in the perilymph, as well as reduced cochlear blood flow [12]. However, morphological studies found no obvious anatomical changes in the structure of inner ear, including the hair cells and vascular and supporting tissues in the cochlea [1]. Boettcher and Salvi reported that treatment with $300-450 \mathrm{mg} / \mathrm{kg}$ salicylate did not cause hair cell loss in chinchillas [13]. The same results were reported in other research, demonstrating that salicylate does not alter the number or distribution of hair cells $[13,14]$. Other authors reported that salicylate might inhibit the electromotility of outer hair cells, resulting in hearing loss and tinnitus [15, 16]. Studies also revealed that salicylate might induce tinnitus through activation of cochlear NMDA receptors and up-regulation of NR2B, TNF- $\alpha$, and IL- $1 \beta$ expression in the cochlea and hair cells [17, 18]. Investigating the micro-morphological changes in the hair cells and related mechanisms during the process of salicylate-induced tinnitus may benefit both the study of tinnitus and the development of therapies for it.

Recently, studies have demonstrated that inner hair cells (IHCs) in the cochlea are involved in the pathological process of tinnitus induced by noise exposure and salicylate [19, 20]. IHCs are responsible for transmitting signals of sound frequency and intensity to the central nervous system (CNS) in mammals [21]. The synaptic terminals of IHCs are ribbon synapses, a type of special proteinaceous organelle that tethers large numbers of synaptic vesicles near the active zone where neurotransmission occurs [22]. Ribbon synapses acquired their name due to their ribbon-shaped spatial distribution, and they function as a synaptic connection between IHCs and the afferent nerve endings of spiral ganglion neurons by releasing neurotransmitters [23-25]. Effective IHC synaptic ribbons are essential for normal auditory signaling and hearing [26]. Significant losses of IHC ribbon synapses accompanied by hearing impairment can be observed in noise-induced tinnitus [27, 28]. Nevertheless, the mechanisms by which ototoxicity causes damage to synaptic ribbons are still unknown. We hypothesized that changes in the number or distribution of ribbon synapses might be one possible mechanism in the salicylate-induced tinnitus. The main component of synaptic ribbons is RIBEYE, a protein purified from the ribbon synapses of the retina by Schmitz et al in 2000 [29]. RIBEYE is highly conserved in vertebrates and is specific to synaptic ribbons [29]. Later studies revealed that RIBEYE is also expressed in hair cells [30]. It contributes to the normal structure and function of IHCs as well as ribbon synaptogenesis, and it maintains the normal acoustic and vestibular functions of the cochlea by evoking innervation of the afferent nerve and affecting the calcium channels localized in the ribbon active zones of hair cells [8]. However, the changes in RIBEYE due to salicylate-induced tinnitus have remained unclear. We hypothesized that the alteration of RIBEYE expression levels is associated with morphological changes of ribbon synapses during the pathological process of tinnitus. 


\section{Cellular Physiology and Biochemistry}

Cell Physiol Biochem 2014;34:753-767

\begin{tabular}{l|l}
\hline DOI: $10.1159 / 000363040$ & (C) 2014 S. Karger AG, Basel
\end{tabular}

www.karger.com/cpb

Zhang et al.: Ribbon Synaptic Number and RIBEYE Expression in Tinnitus

Therefore, the clinically relevant aim of this work is to reveal the basic evidence related to salicylate-induced tinnitus and to assist future studies in developing safer and more efficient applications of salicylate in clinical practice.

In the present study, we aimed to investigate the effects of the administration of salicylate on the morphology and quantity of ribbon synapses in the process of tinnitus. Furthermore, we also aimed to investigate the changes in RIBEYE expression levels in the process.

\section{Materials and Methods}

Animals

Two-month-old C57BL/6J mice were provided by the Laboratory Animal Center at China Medical University (Shenyang, China). Their auditory brainstem response (ABR) results were normal. Mice with outer and middle ear diseases were excluded from the experiments. All procedures were performed in accordance with the animal protocol approved by the animal care and use committee and with the guide for the care and use of laboratory animals (NIH Publication No. 85-23, revised 1996).

\section{Antibodies}

Goat anti-mouse CtBP2 (E-16) (Santa Cruz, CA, USA, diluted at 1:100), rabbit anti-mouse GluR $2 \& 3$ (Chemi Con, CA, USA, $2 \mu \mathrm{g} / \mathrm{mL}$ ), bovine anti-goat IgG FITC (Santa Cruz, CA, USA, diluted at 1:100) and donkey anti-rabbit IgG TR (Santa Cruz, CA, USA, diluted at 1:100) antibodies were utilized in this work.

\section{Optimal conditioning stimulus}

Animals were randomly divided into four groups ( $\mathrm{n}=5$ in each group) according to the conditioned stimuli of various sound frequency levels $(4,10,16$ or $24 \mathrm{kHz})$ at the same intensity level of $60 \mathrm{~dB}$. Then, correct responses to real auditory stimuli and responses to phantom sound sensations or tinnitus (represented as false positive responses) were measured on the third day after a salicylate injection [9]. Animals were also divided into three groups ( $\mathrm{n}=5$ in each group) according to conditioned stimuli intensity levels of 30, 60 or $90 \mathrm{~dB}$ SPL (16 kHz), and false positive responses were measured as described above. The active avoidance score was also checked among all these groups.

\section{Auditory brainstem response (ABR) recording}

Changes in auditory function were evaluated by measuring auditory brainstem responses (ABRs). Auditory thresholds were checked and recorded for each animal immediately and at $24 \mathrm{~h}, 48 \mathrm{~h}, 72 \mathrm{~h}, 120$ h, $168 \mathrm{~h}, 192 \mathrm{~h}, 216 \mathrm{~h}$ and $240 \mathrm{~h}$ after the injection of salicylate in the $1 \mathrm{~d}, 2 \mathrm{~d}, 3 \mathrm{~d}, 5 \mathrm{~d}, 7 \mathrm{~d}, 8 \mathrm{~d}, 9 \mathrm{~d}$ and $10 \mathrm{~d}$ groups, respectively, before and after the administration of salicylate. The positive needle electrode was inserted subdermally at the midline of the vertex of the scalp between the external auditory canals, the negative electrode was placed below the pinna of the left ear and the ground electrode was placed contralaterally. Tone bursts of 8,16 and $24 \mathrm{kHz}$ (10 ms duration, $1 \mathrm{~ms}$ rise and fall time) were generated using Smart-EP by Intelligent Hearing Systems (USA) and delivered to the left external auditory meatus in a closed acoustic system through an ear bar connected to a DT-48 transducer (Beyer Dynamic, Farmingdale, N.Y.). Responses from 1020 stimuli were averaged for each frequency and fed to an amplifier. Amplification was viewed using an oscilloscope and recorded. Thresholds were determined by reducing the sound intensity in $5 \mathrm{~dB}$ steps until thresholds were reached, which were defined as the lowest intensity that yielded a reproducible deflection in the evoked response trace. Thresholds were verified at least twice. Threshold shifts were calculated for individual animals by comparing the results with their pre-exposure thresholds.

\section{Drug administration}

The mice were randomly divided into the salicylate group and control group. Salicylate (350 mg/kg) was injected intraperitoneally on the $1^{\text {st }}, 3^{\text {rd }}, 5^{\text {th }}, 7^{\text {th }}, 8^{\text {th }}, 9^{\text {th }}$ and $10^{\text {th }}$ days of the experiment for the salicylate group. The experimental group consisted of ten mice that were not administered salicylate on day 0 . In the control group, mice received the same amount of saline on the same days. 
Cellular Physiology
and Biochemistry

Cell Physiol Biochem 2014;34:753-767

DOI: $10.1159 / 000363040$

Publisned Onilne: August 19, 2014

C) 2014 S. Karger AG, Basel

www.karger.com/cpb

Fig. 1. The ideograph represents the behavioral protocol of the mice. Subjects were conditioned to jump onto the wall in response to an auditory stimulus. Each session included 10 trials. The conditioning procedure required up to seven sessions lasting 15-20 min (i.e., 2 or $3 \mathrm{~d}$ ). When conditioned (criterion: 3 consecutive sessions with an active avoidance score $\geq 80 \%$ ), the animals were included in the experiments. The behavioral testing protocol (10 time points) consisted of a daily measurement of correct responses to sounds (active avoidance scores) and jumps onto the wall during inter-trial periods (false positive responses) in a 15 min session. Saline or salicylate was injected daily $2 \mathrm{~h}$ before the testing session.

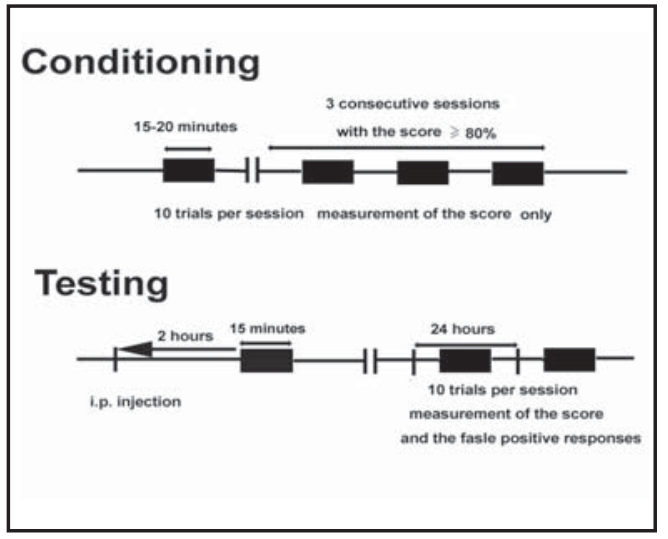

\section{Behavioral procedure}

Animals were housed individually in a temperature-controlled room on a constant $12 \mathrm{hr}$ light/ dark cycle. All behavioral tests were conducted during the animals' activity period (the dark phase) at approximately the same time each day. Food and tap water were available in the home cage throughout the experiments. The behavioral protocol of the mice is displayed in Fig. 1.

Animals were trained to perform an active avoidance task [18, 31]. Both "conditioning" and "testing" were performed in a conditioning box that was divided into two parts by a low wall ( $3 \mathrm{~cm}$ high), with one part of the box containing an electrified floor. The conditioning box was placed in a soundproof room. The conditioning paradigm consisted of dispatched sessions. A session of 10 trials, lasting 30 min, was performed daily. A 5 s pure tone sound was used as the "conditioning stimulus," and the unconditioned stimulus was a $3.7 \mathrm{~mA}$ electrical foot shock presented for a maximum of $8 \mathrm{sec}$. The time interval between conditioned and unconditioned stimuli was $2 \mathrm{~s}$. Electrical shocks were stopped if the animal correctly jumped over the low wall and fled from the electrified floor. The inter-trial interval was $3 \mathrm{~min}$. The score was the level of performance as assessed by the number of times the rat correctly climbed in response to sound. Animals were considered conditioned when the level of performance reached at least $80 \%$ in three consecutive sessions. After 10-14 days, the mice were trained to associate auditory stimuli with the electrical shock, which formed the behavioral conditioned reflex: jumping over the low wall in response to auditory stimuli. The animals then received daily intraperitoneal injections of normal saline alone $(n=10)$ or $350 \mathrm{mg} / \mathrm{kg}$ salicylate $(n=10)$ for $10 \mathrm{~d}$. The behavioral task was performed at $24 \mathrm{~h}, 48 \mathrm{~h}, 72 \mathrm{~h}, 120 \mathrm{~h}, 168$ h, $192 \mathrm{~h}, 216 \mathrm{~h}$ and $240 \mathrm{~h}$ after the injection of salicylate in the $1 \mathrm{~d}, 2 \mathrm{~d}, 3 \mathrm{~d}, 5 \mathrm{~d}, 7 \mathrm{~d}, 8 \mathrm{~d}, 9 \mathrm{~d}$ and $10 \mathrm{~d}$ groups, respectively. Two parameters were measured: the number of correct responses to sound (score) and the number of responses without sound (false positives).

\section{Behavioral testing}

Once conditioned (i.e., score $\geq 80 \%$ in three consecutive sessions), the animals were included in the experiments. The behavioral testing protocol consisted of a daily measurement of both the score (correct responses to sound) and false positive responses (incorrect responses to phantom sound sensations). False positive responses were the number of times the animal climbed the wall during inter-trial periods (i.e., responses during silent periods). If animals stayed on the wall for over $10 \mathrm{sec}$, they were put down on the floor. Trials were randomized, and electrical foot shocks were only presented if the animal did not climb in response to sound. Regardless of the score and number of false positive responses, each session included 10 trials and lasted $30 \mathrm{~min}$. Both scores and false positive responses were measured in the same session.

\section{Double-labeled immunofluorescent staining}

Mouse cochleae were removed and fixed at 24 h, 48 h, 72 h, 120 h, 168 h, 192 h, $216 \mathrm{~h}$ and 240 h after the injection of salicylate in the $1 \mathrm{~d}, 2 \mathrm{~d}, 3 \mathrm{~d}, 5 \mathrm{~d}, 7 \mathrm{~d}, 8 \mathrm{~d}, 9 \mathrm{~d}$ and $10 \mathrm{~d}$ groups, respectively. After anesthetization with $10 \%$ chloral hydrate, the animals were decapitated, and the cochleae were quickly taken out, washed in PBS and fixed in 4\% paraformaldehyde. The round and oval windows were opened, and the bone over the apical turn was removed to allow for rapid flushing of $4 \%$ paraformaldehyde in PBS 


\section{Cellular Physiology and Biochemistry}

Cell Physiol Biochem 2014;34:753-767

DOI: $10.1159 / 000363040$

Publisned online: August 19, 2014

(C) 2014 S. Karger AG, Basel

www.karger.com/cpb

Zhang et al.: Ribbon Synaptic Number and RIBEYE Expression in Tinnitus

through the cochlear scalae followed by brief $(10 \mathrm{~min})$ postfixation at $4^{\circ} \mathrm{C}$. After postfixation, the cochleae were washed with PBS, and the thin bone over the middle-ear-facing portion of the cochlear spiral and the tectorial membrane were removed with fine forceps under a microscope (Olympus SDF PLAPO Japan). Without decalcification or further dissection, the cochleae were immediately immunostained. The separated apical and middle cochlear turns (1-1.5 mm in length from the apex of the cochlea) were placed in $0.5 \%$ Triton X-100 for $30 \mathrm{~min}$ and then washed with $0.01 \mathrm{mmol} / \mathrm{L}$ PBS three times. Confining liquid containing $5 \%$ goat serum and $2 \%$ BSA was used to block non-specific sites for $2 \mathrm{~h}$, and then goat anti-mouse C-terminal binding protein 2 (CtBP2, E-16) antibodies (1:100) and rabbit anti-mouse glutamate receptor $2 \& 3$ (GluR $2 \& 3)$ antibodies $(2 \mu \mathrm{g} / \mathrm{mL})$ were added and reacted at $37^{\circ} \mathrm{C}$ overnight. The basilar membranes were washed with PBS three times, stained with donkey anti-rabbit IgG TR $(1: 100)$ at $37^{\circ} \mathrm{C}$ for $1 \mathrm{~h}$ in a dark environment and then washed with PBS three times. Finally, the basilar membranes were stained with bovine anti-goat IgG FITC $(1: 100)$ at $37^{\circ} \mathrm{C}$ for $1 \mathrm{~h}$ in a dark environment. At the beginning of the primary incubation, some ears were subjected to seven cycles of microwave radiation at $150 \mathrm{~W}$ (on for $3 \mathrm{~min}$, off for $3 \mathrm{~min}$ ). Following the final antibody linkage step, the tissue was further fixed by immersion in $4 \%$ paraformaldehyde in PBS for $30 \mathrm{~min}$ on a shaker at room temperature. After immunostaining, the cochleae were decalcified in 0.12 M EDTA overnight at $4^{\circ} \mathrm{C}$ and dissected into five or six pieces, mounted on microscope slides in VectaShield and coverslipped, washed with PBS three times, and washed with distilled water once. Finally, stretched preparations were examined under a dissecting microscope.

\section{Laser scanning confocal microscopic imaging}

The excitation wavelengths of the laser scanning confocal microscope (Leica TCS SP2 AOBS) were $488 \mathrm{~nm}$ and $543 \mathrm{~nm}$. Sequence scanning was performed in the apical and middle turns of the IHCs with an interval of $0.12 \mu \mathrm{m}$. Double labeling was performed with FITC and TR as the secondary antibodies; doublelabeled fluorescein color pairs were viewed as orange fluorescence. The samples were scanned layer by layer with a laser confocal microscope. Scanning began at the first layer in which fluorescein color pairs appeared and ended at the first layer that lacked fluorescein color pairs. Thus, a series of two-dimensional images were obtained in one visual field. Sequential images from each group were placed in a file and numerically ordered. Sequential scanning of the parietal gyri of ten basilar membranes was performed. One visual field from each basilar membrane was selected for scanning, and ten files were obtained. The number of IHCs in one layer was also counted, and the number of layers was recorded for each visual field.

\section{Three-dimensional model made with 3ds MAX}

The two-dimensional images were analyzed using 3ds MAX to count the number of ribbon synapses. The cochlear portion used for 3ds MAX analysis was 1-1.5 mm long from the apex. The two-dimensional images were placed in the $3 \mathrm{~d}$ s MAX top view window t o serve as the view port background. Orange fluorescent spots in each layer of immunostaining were replaced by different colored balls. The next layer was then analyzed in the same way. The series of two-dimensional image layers were overlayed one by one, and three-dimensional distributions of ribbon synapses were displayed as different colored balls in $3 \mathrm{~d}$ MAX. If orange fluorescence appeared in the same position as in the previous image, the marker was not required, because it was considered to be the same synapse. If orange fluorescence appeared in other positions, indicating a new synapse in the slice, another marker was made. Finally, the ribbon synapse number was obtained. The total number of colored balls in each visual field was counted to present the total number of ribbon synapses, and the relative number of ribbon synapses was calculated as the number per IHC. The relative numbers were compared and statistically analyzed.

\section{Reverse transcription-polymerase chain reaction (RT-PCR)}

The cochleae were removed and prepared at 24 h, 48 h, 72 h, 120 h, 168 h, 192 h, 216 h and 240 h after the injection of salicylate in the $1 \mathrm{~d}, 2 \mathrm{~d}, 3 \mathrm{~d}, 5 \mathrm{~d}, 7 \mathrm{~d}, 8 \mathrm{~d}, 9 \mathrm{~d}$ and $10 \mathrm{~d}$ groups, respectively, as described above. The mice were anesthetized with $35 \%$ chloral hydrate (350 mg/kg, IP) and decapitated. The temporal bones were removed and dissected in ice-cold RNase-free PBS to collect the cochleae. The otic capsule was removed, and the remaining whole cochlea was kept at $-70^{\circ} \mathrm{C}$. RNA was isolated from the cochleae and purified with TRIzol reagent (Invitrogen, Camarillo, CA, USA), following the manufacturer's instructions. cDNA was generated from $1 \mu \mathrm{g}$ of total RNA from each sample. The forward and reverse primers of each PCR set, the sizes of the PCR products, GenBank accession numbers, oligonucleotides, and annealing 
Zhang et al.: Ribbon Synaptic Number and RIBEYE Expression in Tinnitus

Table 1. Gene specific primers for RT-PCR. Product sizes and annealing temperatures are also shown

\begin{tabular}{lllcc}
\hline Gene & $\begin{array}{l}\text { GenBank accession } \\
\text { no. }\end{array}$ & Oligonucleotide $\left(5^{\prime}-3^{\prime}\right)$ & $\begin{array}{l}\text { PCR } \\
\text { product } \\
\text { size }(\mathrm{bp})\end{array}$ & $\begin{array}{l}\text { Annealing } \\
\text { temperature } \\
\left({ }^{\circ} \mathrm{C}\right)\end{array}$ \\
\hline Mouse RIBEYE & NM_001170744 & $\begin{array}{l}\text { Forward: GATGCTGCTGGCTGGTATG } \\
\text { Reverse: TAATCTGGTATCAGGCTGTTCC }\end{array}$ & 522 & 54 \\
$\begin{array}{l}\text { Mouse beta } \\
\text { actin }\end{array}$ & NM_007393 & $\begin{array}{l}\text { Forward: GTCCCTCACCCTCCCAAAAG } \\
\text { Reverse: GCTGCCTCAACACCTCAACCC }\end{array}$ & 266 & 55.7 \\
\hline
\end{tabular}

temperatures are displayed in Table 1 . A total of 30 PCR cycles were performed to amplify RIBEYE protein and $\beta$-actin (an internal control). The PCR products were electrophoresed on $2 \%$ agarose gels, and the gels were photographed with a ChemiImager5500 gel image analysis instrument (Alpha Innotech, USA). The integrated density values (IDVs) of the PCR product bands were calculated using a computerized image analysis system (Fluor Chen 2.0) and normalized to that of $\beta$-actin.

\section{Western blot analysis}

For specific detection of RIBEYE in apical coils of the basement membrane, $100 \mathrm{mg}$ of tissue from each group was prepared in $1 \mathrm{ml}$ of an ice-cold lysis buffer (2 mM EDTA, $10 \mathrm{mM}$ EGTA, 0.4\% NaF, $20 \mathrm{mM}$ Tris-HCL, $1 \%$ Triton X-100, 1\% NP-40, protease inhibitors, pH 7.5). An equal amount of protein (50 $\mu \mathrm{g})$ was loaded onto 7.5\% SDS-polyacrylamide gels and electrophoretically transferred to PVDF membranes (Roth, Germany). RIBEYE was detected with a B domain-specific antibody against RIBEYE (anti-CtBP2 antibody, Santa Cruz, USA, diluted at 1:100) using chemiluminescent ECL substrate (Amersham, UK). Stripped blots were re-probed with an anti- $\beta$-actin polyclonal antibody (Santa Cruz, USA).

\section{Statistical analysis}

Statistical analyses were performed using SPSS 13.0, and the data are presented as the mean \pm SD. Student's t-test was used to determine significant differences between two groups. One-way analyses of variance (ANOVA) and post hoc comparisons (Bonferroni tests) were used to determine significant differences among multiple groups. A P value of less than 0.05 was considered to be statistically significant.

\section{Results}

Optimal conditioned stimuli

We first investigated the optimal conditioned stimuli for tinnitus models. Animals were divided into four groups ( $\mathrm{n}=5$ in each group) according to conditioned stimuli of 4 , 10, 16 or $24 \mathrm{kHz}$ (at $60 \mathrm{~dB}$ SPL) in pilot experiments. The results are shown in Fig 2. False positive responses were measured on the $3^{\text {rd }} \mathrm{d}$ after the salicylate injection. The numbers of false positive responses were $0.65 \pm 0.24(4 \mathrm{kHz}), 4.25 \pm 1.05(10 \mathrm{kHz}), 2.25 \pm 0.0 .46(16$ $\mathrm{kHz})$, and $1.03 \pm 0.69(24 \mathrm{kHz})$; the increase for the $10 \mathrm{kHz}$ stimulus was significant $(P<0.01$, Fig. 2A). Then, the animals were divided into three groups ( $n=5$ in each group) according to conditioned stimuli of 30, 60 or $90 \mathrm{~dB}$ SPL (at $10 \mathrm{kHz}$ ), and false positive responses were measured as described above. The numbers of false positive responses were $0.98 \pm 0.26$ (30 $\mathrm{dB}$ SPL), $4.25 \pm 1.12$ (60 dB SPL), and 1.05 \pm 0.25 (90 dB SPL); the increase for the $60 \mathrm{~dB}$ SPL stimulus was statistically significant $(P<0.01$, Fig. $2 \mathrm{~B})$. The active avoidance scores did not show a significant change among any of the groups (Fig. 2C). According to the above data, a pure tone stimulus of $10 \mathrm{kHz}$ presented at $60 \mathrm{~dB}$ SPL was adopted as the most appropriate conditioned stimulus in the following experiments.

False positive responses significantly increased at the 3 rd d after salicylate administration

Animals were conditioned to perform a motor task (i.e., to jump on a wall) in response to the presentation of a sound. We measured the number of false positive responses in the salicylate-treated animals during silent periods. As shown in Fig. 3, salicylate injections 


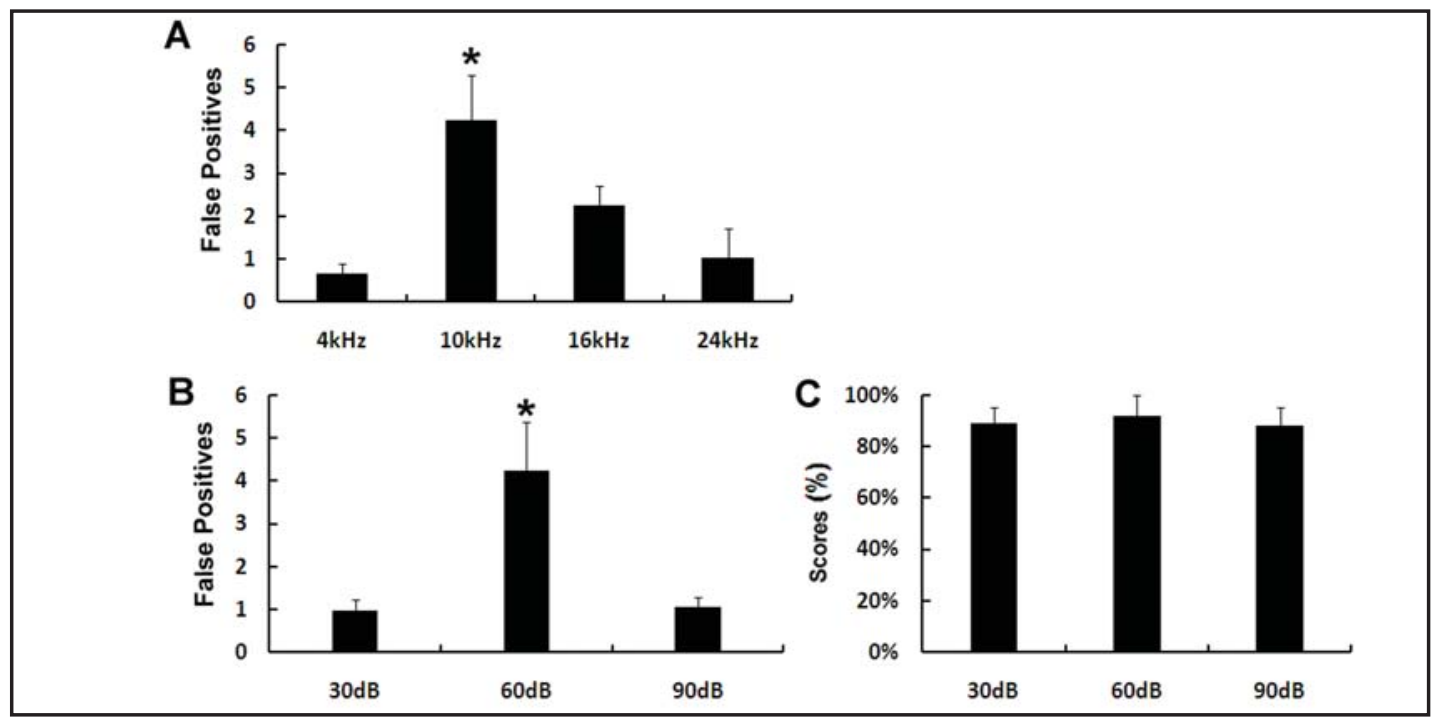

Fig. 2. The most appropriate frequency (kHz) and intensity level (dB SPL) for the conditioning stimulus in the salicylate-induced tinnitus model was determined. (A) Animals were divided into four groups $(n=5$ in each group) according to conditioning stimuli of 4, 10, 16 or $24 \mathrm{kHz}$ ( $60 \mathrm{~dB}$ SPL). The number of false positives was measured on the $3^{\text {rd }} \mathrm{d}$ after the salicylate injection; this number increased significantly when the conditioning stimulus was $10 \mathrm{kHz}\left({ }^{*} P<0.01\right)$. (B) Animals were divided into three groups $(\mathrm{n}=5 \mathrm{in}$ each group) according to conditioning stimuli of 30, 60 or $90 \mathrm{~dB}$ SPL $(10 \mathrm{kHz})$. The number of false positives between these groups on the third day after salicylate administration increased significantly when the conditioning stimulus intensity was $60 \mathrm{~dB}$ SPL $\left({ }^{*} P<0.01\right)$. (C) The percentage of correct responses (score $\left.\%\right)$ to sounds at 30,60 or $90 \mathrm{~dB}$ SPL ( $10 \mathrm{kHz}$ ) (active avoidance score) is described in the picture. There were no significant differences between the three groups.

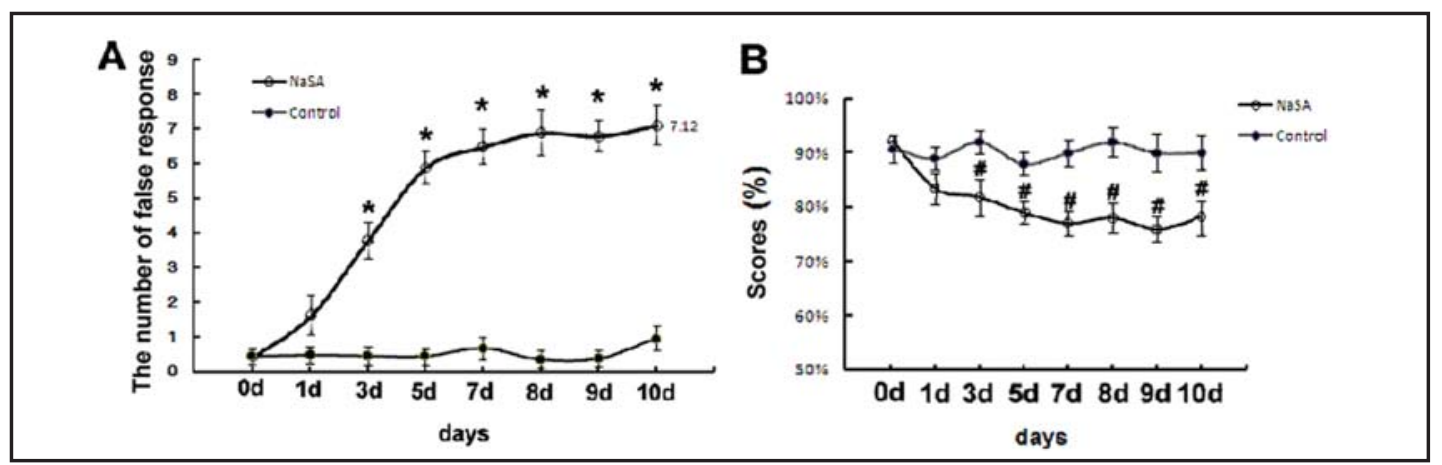

Fig. 3. Measurement of the active avoidance scores and false positive responses in the salicylate and control groups. A represents the number of abnormal jumps during silent periods (false positives) measured at $0 \mathrm{~d}$, $1 \mathrm{~d}, 3 \mathrm{~d}, 5 \mathrm{~d}, 7 \mathrm{~d}, 8 \mathrm{~d}, 9 \mathrm{~d}$ and $10 \mathrm{~d}$ after intraperitoneal injections of saline or salicylate (350 mg/kg). Compared to the control group, salicylate significantly increased the number of false positives on the $3^{\text {rd }} d, 5^{\text {th }} d$, $7^{\text {th }} d, 8^{\text {th }} d, 9^{\text {th }} d$ and $10^{\text {th }} d\left({ }^{*} P<0.05\right)$. B represents the percentage of correct responses to sound (score) in both groups during the experimental periods. Salicylate reduced the scores on the $3^{\text {rd }} d, 5^{\text {th }} d, 7^{\text {th }} d, 8^{\text {th }} d, 9^{\text {th }}$ $\mathrm{d}$ and $10^{\text {th }} \mathrm{d}$ compared to the control group $\left({ }^{\#} P<0.05\right)$.

significantly increased the number of false positives on the $3^{\text {rd }} d(3.8 \pm 0.52), 5^{\text {th }} d(5.9 \pm 0.45)$, $7^{\text {th }} d(6.5 \pm 0.5), 8^{\text {th }} d(6.9 \pm 0.65), 9^{\text {th }} d(6.8 \pm 0.45)$ and $10^{\text {th }} d(7.12 \pm 0.56)(P<0.05)$ compared to the control data, which were $0 \mathrm{~d}(0.45 \pm 0.2), 1^{\text {st }} \mathrm{d}(0.48 \pm 0.25), 3^{\text {rd }} \mathrm{d}(0.46 \pm 0.25), 5^{\text {th }} \mathrm{d}$ $(0.45 \pm 0.24), 7^{\text {th }} d(0.67 \pm 0.33), 8^{\text {th }} d(0.35 \pm 0.26), 9^{\text {th }} d(0.38 \pm 0.25)$, and $10^{\text {th }} d(0.95 \pm 0.35 d)$. The reduction in correct responses may reflect the presence of salicylate-induced hearing loss. Therefore, we also tested the changes in correct responses. Injections of salicylate 
Fig. 4. Estimation of the acoustic sensitivities of mice before and after the administration of salicylate and saline. Black dots and triangles show the means of the threshold shifts for the $8 \mathrm{kHz}$ stimulus before and after the administration of salicylate and normal saline at $0 \mathrm{~d}, 1$ d, 3 d, 5 d, 7 d, 8 d, 9 d and 10 d. No remarkable differences were observed before and after salicylate injections in either the experimental or the control group. There was no significant difference between the two groups.

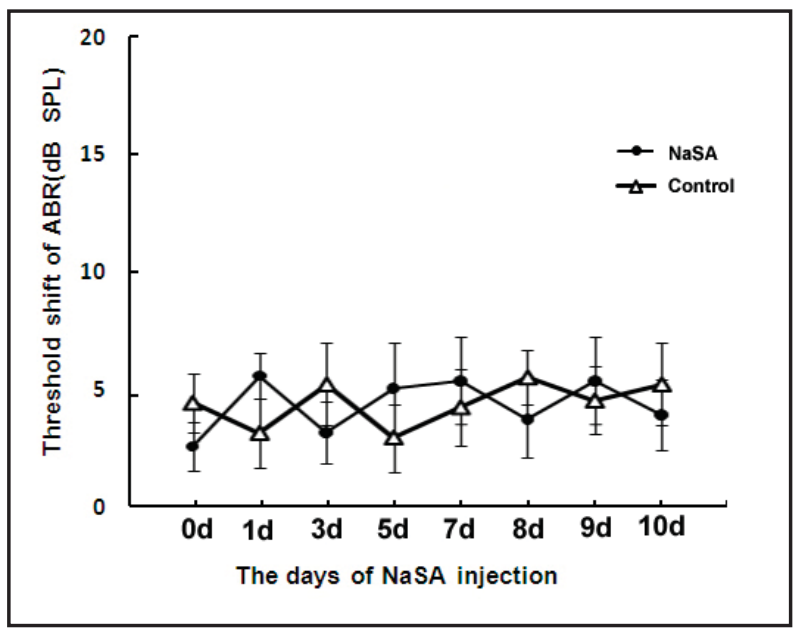

reduced the percentage of correct responses to sound (score) on the $3^{\text {rd }} d(82 \% \pm 3.25 \%)$, $5^{\text {th }} d(79 \% \pm 2 \%), 7^{\text {th }} d(77 \% \pm 2.17 \%), 8^{\text {th }} d(78 \% \pm 2.85 \%), 9^{\text {th }} d(76 \% \pm 2.25 \%)$ and $10^{\text {th }} d$ $(78 \% \pm 3.23 \%)(P<0.05)$.

\section{Salicylate did not cause notable changes in the ABR results}

We examined whether salicylate caused inner ear dysfunction in the mice by performing ABR testing. We used wave III to measure ABR thresholds because this was the most detectable response at lower-intensity reference stimuli. ABR testing was performed at $24 \mathrm{~h}$, $48 \mathrm{~h}, 72 \mathrm{~h}, 120 \mathrm{~h}, 168 \mathrm{~h}, 192 \mathrm{~h}, 216 \mathrm{~h}$ and $240 \mathrm{~h}$ after the injection of salicylate in the $1 \mathrm{~d}, 2 \mathrm{~d}$, $3 \mathrm{~d}, 5 \mathrm{~d}, 7 \mathrm{~d}, 8 \mathrm{~d}, 9 \mathrm{~d}$ and $10 \mathrm{~d}$ groups, respectively. No significant differences were observed between mean ABR threshold shifts in the salicylate and control groups for $8 \mathrm{kHz}$ stimuli (Fig. 4). The ABR results for $16 \mathrm{kHz}$ and $24 \mathrm{kHz}$ stimuli were similar to the $8 \mathrm{kHz}$ results (data not shown).

The number of ribbon synapses was first increased, then decreased after salicylate injections

C57BL/6J mouse basilar membranes in the apical and middle turns of cochleas were excised, membrane samples were subjected to immunofluorescent labeling and scanned using a laser confocal microscope, and the serial sections were used to build three-dimensional models using 3ds MAX software. Ribbon synapses were distributed in the basilar part of the IHCs (Fig. 5). We observed that both the number of bright spots and their densities increased after the application of salicylate for 7 days and gradually decreased from the $7^{\text {th }}$ to the $10^{\text {th }} \mathrm{d}$, indicating that the number of ribbon synapses was increased on the $7^{\text {th }} \mathrm{d}$ after the salicylate injection, then subsequently decreased.

The number of ribbon synapses was significantly changed by salicylate in a time-dependent pattern

We found that IHC profiles were intact in all mice, but the numbers of ribbon synapses in the IHCs were different between groups. As shown in Fig. 6, the number of synaptic ribbons in the inner hair cells of the salicylate group was similar to those of the control group $(16.15 \pm 0.95)$ on the $1^{\text {st }}(15.57 \pm 1.56)$ and $3^{\text {rd }}(15.78 \pm 1.05)$ days, but significantly higher on the $7^{\text {th }} d(21.88 \pm 0.85)$. However, the number of synaptic ribbons in the inner hair cells of the salicylate group was much lower on the $9^{\text {th }} d(12.20 \pm 1.03)$ and $10^{\text {th }} d(7.38 \pm 1.31)$. The number of synaptic ribbons in the inner hair cells of the salicylate injection group was significantly lower than that in the control group on the $10^{\text {th }} \mathrm{d}$ (Fig. 6).

RIBEYE expression was significantly altered in a time-dependent manner by salicylate

RIBEYE is the main protein component expressed specifically in ribbon synapses, contributing to normal IHC structure and function [32]. In the present study, we investigated 


\section{Cellular Physiology and Biochemistry}

Cell Physiol Biochem 2014;34:753-767

DOI: $10.1159 / 000363040$

Publisned oninne: August 19, 2014

Zhang et al.: Ribbon Synaptic Number and RIBEYE Expression in Tinnitus
Fig. 5. Immunofluorescence doublelabeling on ribbon synapses at experimental points (control, $0 \mathrm{~d}, 1 \mathrm{~d}, 3 \mathrm{~d}, 5 \mathrm{~d}$, $7 \mathrm{~d}, 8 \mathrm{~d}, 9 \mathrm{~d}$ and $10 \mathrm{~d}$ ) between the salicylate and control groups. Green fluorescence indicates CtBP2 labeled with FITC and shows that the presynaptic membrane is labeled. Red fluorescence implies GluR 2\&3 labeled with TR and represents the postsynaptic membrane label. Images were produced using two channels. A fluorescent orange dot indicates the presence of a complete ribbon synapse. Three-dimensional modeling for double-labeled fluorescent color pairs was performed using 3DS MAX software. Each marker (ball) is a fluorescent color pair, which indicates the presence of a ribbon synapse. The above pictures show that the number of ribbon synapses increases and then decreases with injections of salicylate for 10 days compared to the control group. Scale bar $=15 \mu \mathrm{m}$.

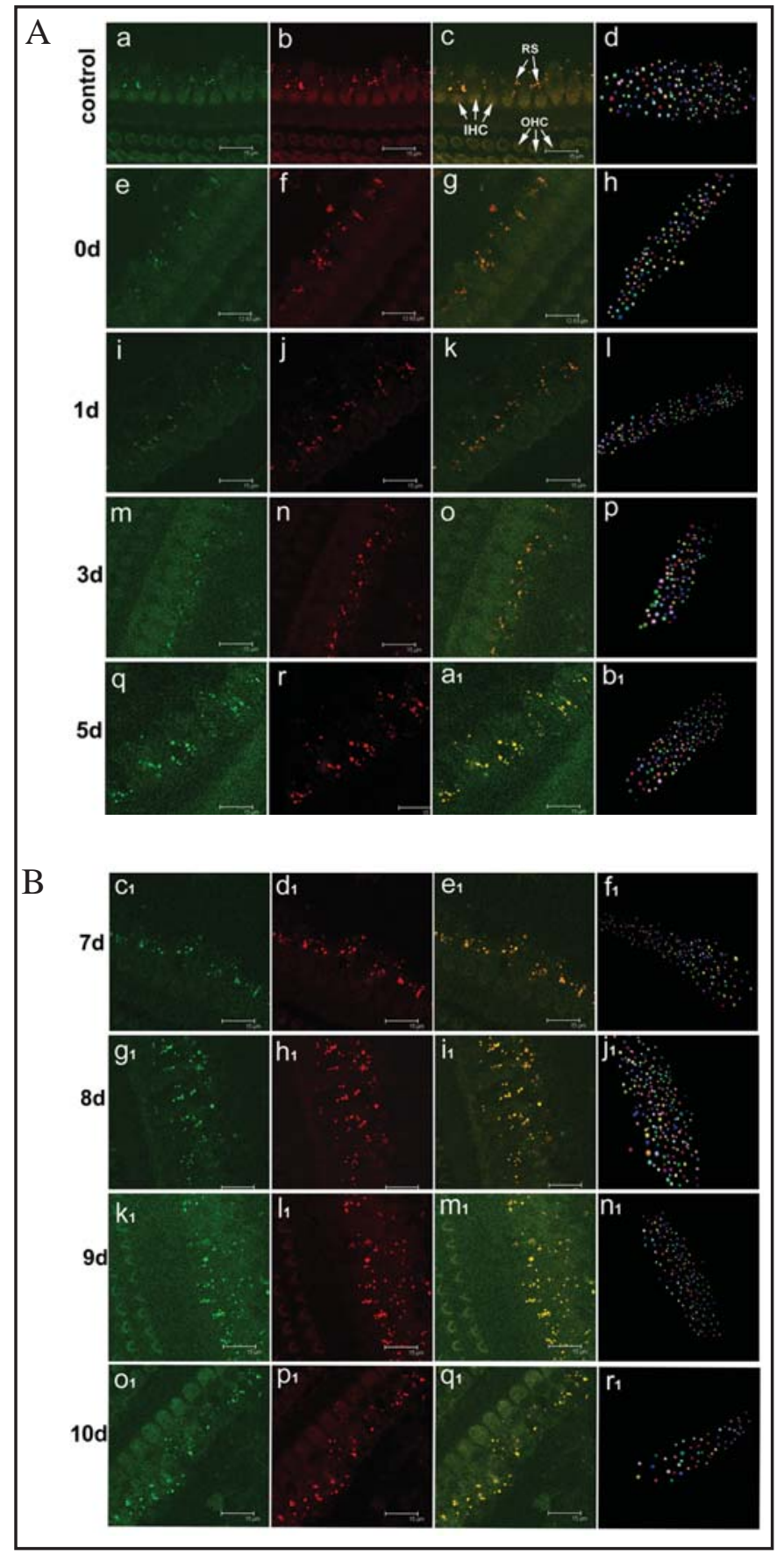

the changes in RIBEYE mRNA expression with salicylate treatment. As shown in Fig. 7, results of RT-PCR revealed that the expression of RIBEYE mRNA displayed a peak-like change with salicylate treatment. The expression of RIBEYE mRNA increased significantly from the $3^{\text {rd }} d$ and reached a peak on the $7^{\text {th }} \mathrm{d}$. However, expression was inhibited on the $8^{\text {th }} \mathrm{d}$ compared to the $7^{\text {th }} \mathrm{d}$. On the $10^{\text {th }} \mathrm{d}$, the expression of RIBEYE mRNA declined to its initial level.

The Western blot results demonstrated that the expression pattern of RIBEYE protein was similar to that of its mRNA (Fig 8). RIBEYE protein expression was up-regulated significantly on the $3^{\text {rd }} \mathrm{d}$ compared with the control group and reached a peak on the $7^{\text {th }}$ $\mathrm{d}$. The expression level then descended from the $8^{\text {th }} \mathrm{d}$ to the $10^{\text {th }} \mathrm{d}$. Taking the results of RT-PCR and the Western blot together, RIBEYE expression changed significantly in a timedependent manner, displaying a peak-like trend under salicylate treatment. This indicates 


\section{Cellular Physiology and Biochemistry}

Cell Physiol Biochem 2014;34:753-767

DOI: 10.1159/000363040

Publisned onime: August 19, 2014

Zhang et al.: Ribbon Synaptic Number and RIBEYE Expression in Tinnitus

Fig. 6. The number of ribbon synapses per IHC was counted using three-dimensional modeling with 3DS MAX software. The numbers of synaptic ribbons in IHCs at $0 \mathrm{~d}, 1 \mathrm{~d}, 3$ $\mathrm{d}$ and $5 \mathrm{~d}$ for the salicylate group were similar to the numbers in the control group; however, this number was higher in the salicylate group versus the control group on the $7^{\text {th }} \mathrm{d}$ $\left({ }^{*} P<0.01\right)$ and lower in the salicylate group versus the control group on the $9^{\text {th }} \mathrm{d}$ and $10^{\text {th }}$ $\mathrm{d}\left({ }^{*} P<0.01\right)$.

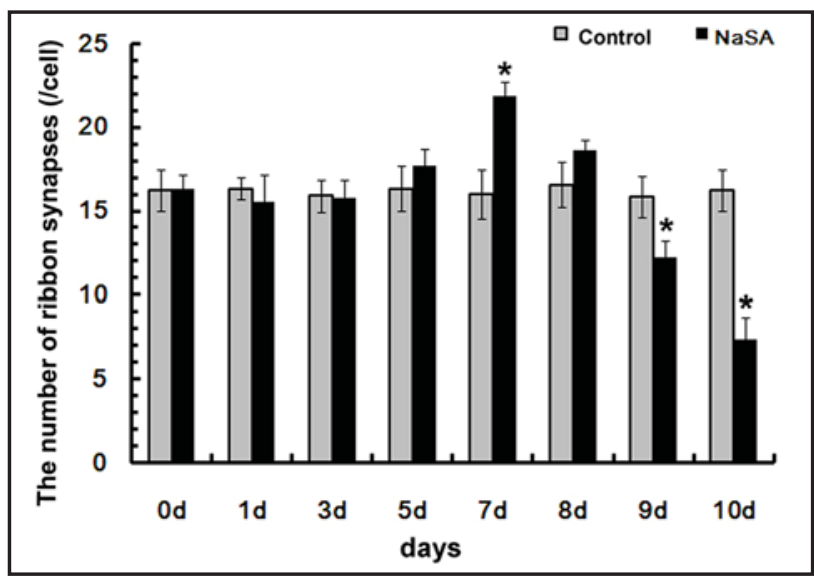

Fig. 7. RT-PCR results for RIBEYE mRNA expression under the administration of salicylate at different time points $(0 \mathrm{~d}, 1 \mathrm{~d}, 3 \mathrm{~d}, 5 \mathrm{~d}, 7$ d, $8 \mathrm{~d}, 9 \mathrm{~d}$ and $10 \mathrm{~d}$ ). mRNA expression did not change on the $1^{\text {st }} \mathrm{d}$. It increased significantly beginning on the $3^{\text {rd }} \mathrm{d}$ and reached its highest point on the $7^{\text {th }} \mathrm{d}$. The expression then declined beginning on the $8^{\text {th }} \mathrm{d}$. On the $10^{\text {th }} \mathrm{d}$, the expression of RIBEYE mRNA declined to its initial level at 0 d. A, Results of RT-PCR. The results revealed that the ex-

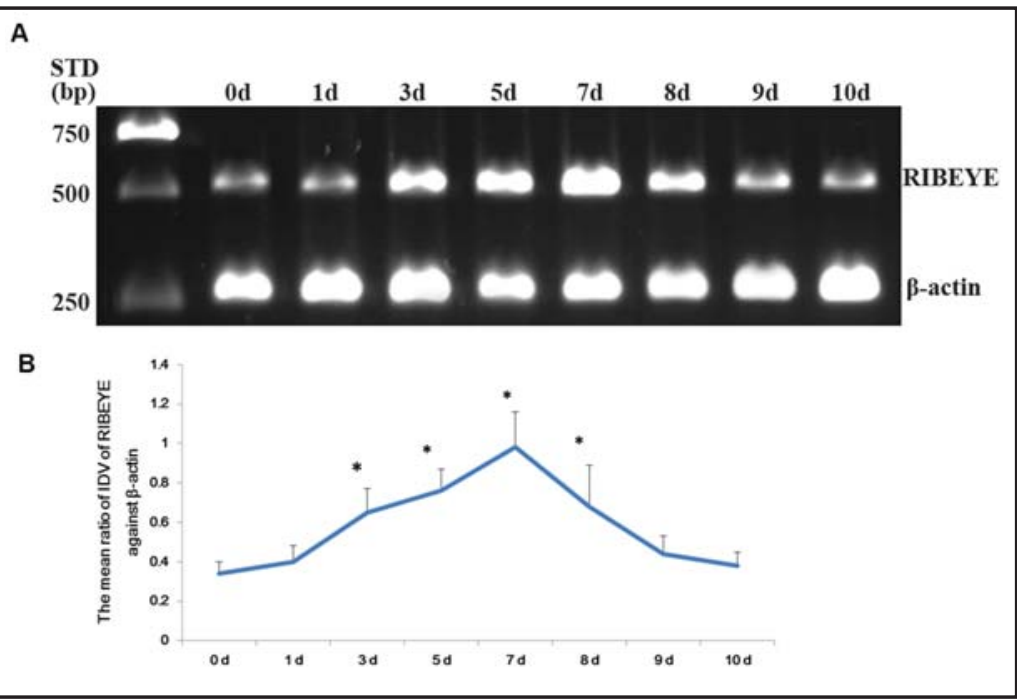
pression of RIBEYE mRNA displayed a peak-like change under salicylate treatment. B, Statistical analysis. * $P<0.05$ vs 0 d group. $\mathrm{N}=5$.

Fig. 8. Western blot results of RIBEYE protein expression under the administration of salicylate at different time points $(0 \mathrm{~d}, 1 \mathrm{~d}, 3 \mathrm{~d}, 5 \mathrm{~d}, 7 \mathrm{~d}, 8$ $\mathrm{d}, 9 \mathrm{~d}$ and $10 \mathrm{~d}$ ). RIBEYE protein expression displayed no significant difference compared to the $0 \mathrm{~d}$ group on the $1^{\text {st }} \mathrm{d}$. It was increased significantly beginning on the $3^{\text {rd }} \mathrm{d}$ and reached its highest point on the $7^{\text {th }} \mathrm{d}$. The expression

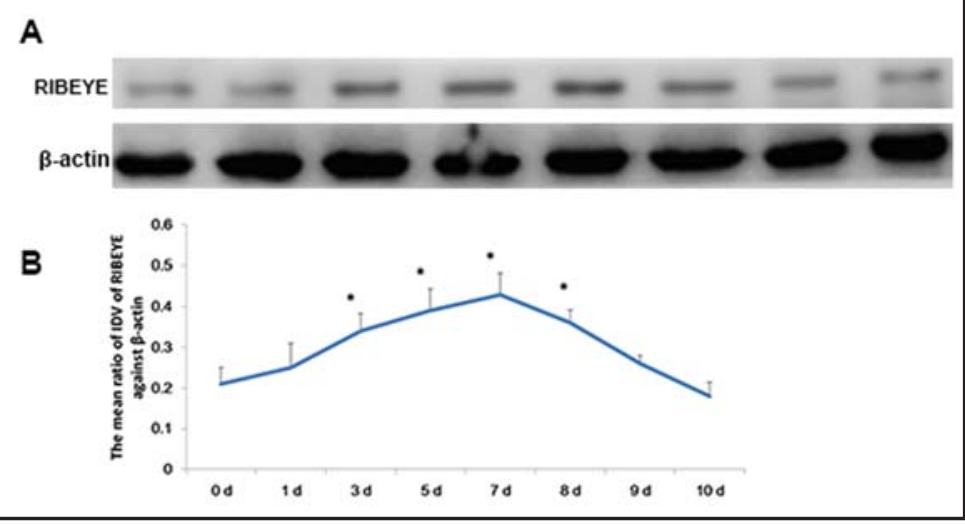
then declined beginning on the $8^{\text {th }} \mathrm{d}$. On the $10^{\text {th }} \mathrm{d}$, the expression of RIBEYE was decreased to its initial level at $0 \mathrm{~d}$. A, Results of the Western blot. The results revealed that the expression of RIBEYE displayed a peaklike change under salicylate treatment. B, Statistical analysis. ${ }^{*} P<0.05$ vs 0 d group. $N=5$.

that the change in RIBEYE might serve as a compensatory mechanism that is subsequently decompensated, or it may indicate a type of negative feedback in salicylate-induced tinnitus. 


\section{Cellular Physiology and Biochemistry}

Cell Physiol Biochem 2014;34:753-767

\begin{tabular}{l|l}
\hline DOI: $10.1159 / 000363040$ & C 2014 S. Karger AG, Basel
\end{tabular}

www.karger.com/cpb

Zhang et al.: Ribbon Synaptic Number and RIBEYE Expression in Tinnitus

\section{Discussion}

In this work, we first aimed to establish the optimal conditioning stimulus and investigated whether salicylate could induce tinnitus in C57BL/6J mice using behavioral assessment. It has been proposed that salicylate could induce tinnitus at a relatively high frequency of $10-16 \mathrm{kHz}$ and $40-60 \mathrm{~dB}$ SPL in rats [1, 18, 31, 33-35]. We found that the most appropriate stimulus frequency and intensity were $10 \mathrm{kHz}$ and $60 \mathrm{~dB}$ SPL, which might not be comparable to previous studies because the animal models and stimulus conditions were different. The behavioral assessment results showed that the number of false positives and the percentage of correct responses increased and decreased from the $3^{\text {rd }} \mathrm{d}$ respectively, indicating that salicylate-induced tinnitus occurs in animal models. ABRs were recorded to investigate changes in auditory brainstem function under the administration of salicylate. The results showed no significant differences between the mean ABR threshold shift in the control group and the salicylate group on days 0-10. Then, we investigated the effects of salicylate on the morphology and quantity of ribbon synapses as well as RIBEYE expression levels in the process of tinnitus. The results demonstrated a peak-like change in the ribbon synapses. The amount and distribution of ribbon synapses increased from the $5^{\text {th }} \mathrm{d}$, reached a maximum on the $7^{\text {th }} \mathrm{d}$, then reduced gradually and finally decreased significantly below the initial level. Similarly, the expression of RIBEYE mRNA and protein also reached a maximum on the $7^{\text {th }} \mathrm{d}$ and returned to the initial $(0 \mathrm{~d})$ level on the $10^{\text {th }} \mathrm{d}$. To the best of our knowledge, this is the first study that revealed alterations in IHC ribbon synapses and RIBEYE protein expression in the process of salicylate-induced tinnitus.

Salicylate, a widely used anti-inflammatory drug, has been shown to induce tinnitus [58, 36-38]. In this work, we performed experiments with salicylate at a concentration of 350 $\mathrm{mg} / \mathrm{kg}$ based on the literature [4, 39-43]. The mechanism of salicylate-induced tinnitus and biological changes related to it remain unclear. It would be of great importance to investigate the effects and mechanisms of salicylate on tinnitus to clarify the pathological mechanism of tinnitus, to develop therapies for tinnitus and to use salicylate more safely. The injection of salicylate leads to a drastic increase in the number of false positive responses according to the literature $[9,18]$. These reports are consistent with our findings. In the present study, we found that the number of false positives increased significantly and the percentage of correct responses decreased from the $3^{\text {rd }} \mathrm{d}$ to the $10^{\text {th }} \mathrm{d}$, indicating that the animals in the salicylate group might be experiencing phantom sounds (tinnitus) from the $3^{\text {rd }} \mathrm{d}$ to the $10^{\text {th }}$ d. ABR thresholds were recorded immediately and at 24 h, 48 h, 72 h, 120 h, 168 h, 192 $\mathrm{h}, 216 \mathrm{~h}$ and $240 \mathrm{~h}$ after the injection of salicylate in the $1 \mathrm{~d}, 2 \mathrm{~d}, 3 \mathrm{~d}, 5 \mathrm{~d}, 7 \mathrm{~d}, 8 \mathrm{~d}, 9 \mathrm{~d}$ and $10 \mathrm{~d}$ groups, respectively. Interestingly, we found no significant difference in the mean ABR threshold shift between the salicylate and control groups. Previous morphological studies have also revealed that salicylate did not change the structure of the inner ear or the number or distribution of IHCs $[1,13,14,44]$. In the present study, the fact that salicylate did not change ABR thresholds indicates that salicylate did not cause any hearing impairment, which should be avoided in the study of tinnitus. However, our previous study demonstrated that gentamicin, a common ototoxic drug, could cause significant hearing damage as well as changes to ABR thresholds [45]. The difference in ABR results might be due to the use of different ototoxic agents (salicylate versus gentamicin). The ototoxicity of gentamicin causes hearing loss while that of salicylate results in tinnitus. ABRs may not precisely reflect ribbon synaptic function, which occurred in the local region between IHCs and SGNs because ABRs are the far-field reflections of potentials arising in the cochlea, auditory nerve, and auditory brainstem pathway. Other targets in the cochlea, such as OHCs, IHCs, and SGNs may also be involved [21]. Combined with the unchanged ABR, it might be reasonable to infer that the administration of salicylate does not cause any obvious damage to the auditory nucleus in the brain stem. Thus, it is reasonable to consider that salicylate may cause tinnitus through micro-morphological and molecular changes in ribbon synapses. Therefore, it is necessary to further investigate the micro-morphological and molecular changes that may be occurring in salicylate-induced tinnitus. 


\section{Cellular Physiology and Biochemistry}

Cell Physiol Biochem 2014;34:753-767

\begin{tabular}{l|l}
\hline DOI: $10.1159 / 000363040$ & (C) 2014 S. Karger AG, Basel
\end{tabular}

www.karger.com/cpb

Zhang et al.: Ribbon Synaptic Number and RIBEYE Expression in Tinnitus

Ribbon synapses, the synaptic terminals of IHCs, function as synaptic connections between IHCs and afferent nerve endings of the spiral ganglion neurons by releasing proteinaceous neurotransmitters from synaptic vesicles near the active zones of IHCs [2225]. The normalization of IHC synaptic ribbons is essential for hearing [26]. However, very few studies could be found describing the changes in ribbon synapses. We hypothesized that the number or distribution of ribbon synapses might be changed in the salicylate-induced tinnitus process, which could be one possible mechanism for salicylate-induced tinnitus. As shown in Fig 5 and Fig 6, our results demonstrated that the IHC profiles were intact in all of the mice, but the numbers of IHC ribbon synapses were different between the salicylate and control groups. The numbers of synaptic ribbons in IHCs were similar between the salicylate and control groups on the $1^{\text {st }}$ and $3^{\text {rd }} \mathrm{d}$. The number and distribution of ribbon synapses peaked on the $7^{\text {th }} \mathrm{d}$ and decreased from the $8^{\text {th }} \mathrm{d}$ to the $10^{\text {th }} \mathrm{d}$, which was consistent with the gentamicin study [21]. In particular, the salicylate group results were significantly lower than the control group results on the $10^{\text {th }} \mathrm{d}$. Changes in the numbers of ribbons seemed to lag behind behavioral measures and molecular changes in RIBEYE. Reasons for this may include the following factors: first, the alteration of ribbon synapse distributions might be too subtle during the first few days. The production of ribbon synapses might be slower than the changes in the molecular expression of proteins and, therefore, require more time to be observable. The increase in the ribbon number might also be accelerated in the middle of the administration, as observed on the 7th day, which is the inflection point of the process. Second, changes in RIBEYE expression might cause changes to the molecular structure and biophysiological function of the ribbon synapses that occur before the number of synapses changes. The mechanisms underlying noise-induced hearing loss and tinnitus may be different from those of salicylate-induced tinnitus. Ribbon loss can be observed in noise-induced tinnitus [27], and it might serve as a negative feedback mechanism to reduce sound transduction into the central nervous system in the presence of noise. However, auditory signal transduction might be reduced in the acoustic injury induced by salicylate, with ribbon synapses increasing as a positive feedback or compensatory mechanism. Our previous study also revealed that the change in ribbon numbers took place prior to that of IHCs in animal models of tinnitus, indicating that ribbon synapses might be more sensitive to ototoxic agents [45]. This finding revealed that the distribution of IHC ribbon synapses served as a compensatory mechanism in the early stage of tinnitus and decompensated if ototoxic damage continued.

There are multiple factors that may explain why salicylate can damage IHCs. First, salicylate may influence the physiological function of IHCs by reducing their outward potassium currents [20]. Salicylate could also reduce synaptic transmission in the medial geniculate body, causing abnormal thalamic outputs to the auditory cortex and contributing to salicylate-induced tinnitus [42]. Hence, the number of synaptic ribbons will be increased as a compensatory mechanism in the first 7 days after salicylate administration. Second, the concentration of $\mathrm{Ca}^{2+}$ in the presynaptic membrane will be raised, as salicylate acts as a carrier of $\mathrm{Ca}^{2+}$. It causes up-regulation of glutamate receptor expression on the postsynaptic membrane, resulting in glutamic acid-induced neurotoxicity to auditory neurons [46]. Third, salicylate might alter the genetic expression of RIBEYE, the main component of synaptic ribbons [29]. RIBEYE is specific to synaptic ribbons and contains an $\mathrm{N}$-terminal A domain and a C-terminal B domain that is identical to CtBP2, a transcriptional repressor related to D-isomer- specific 2-hydroxyacid dehydrogenases [29]. RIBEYE plays a crucial role in maintaining the normal structure and function of hair cells, ribbon synaptogenesis and the normal acoustic and vestibular functions of the cochlea [32]. We supposed that the expression of RIBEYE might be altered along with the number of ribbon synapses in salicylate-induced tinnitus. The results of RT-PCR and Western blot assays demonstrated that the expression of RIBEYE mRNA and protein was up-regulated by the stimulus of salicylate, which might result in an increase in the quantity of ribbon synapses during the first stages of salicylate-induced tinnitus. Consistent with the data obtained with ribbon synapses, RIBEYE expression was inhibited in the final stage of ototoxic salicylate exposure. This phenomenon indicated that 


\section{Cellular Physiology and Biochemistry}

Cell Physiol Biochem 2014;34:753-767

\begin{tabular}{l|l}
\hline DOI: $10.1159 / 000363040$ & (C) 2014 S. Karger AG, Basel
\end{tabular}

www.karger.com/cpb

Zhang et al.: Ribbon Synaptic Number and RIBEYE Expression in Tinnitus

the increased expression of RIBEYE might be a type of compensatory feedback mechanism during the early stages of salicylate-induced acoustic injuries and would ultimately be inhibited, or it could function as a decompensatory or negative feedback mechanism if the ototoxic damage continued. Ribbon synapses may undergo reconstruction or exhibit molecular structural alterations, resulting in unparalleled changes to RIBEYE expression and ribbon numbers. However, details on the role of and alterations to RIBEYE are still unclear and merit further research. Taking these results together, it might be reasonable to infer that the alteration of RIBEYE expression and function could be one possible mechanism underlying salicylate-induced tinnitus.

In conclusion, this study suggested that tinnitus in mice can be induced by salicylate and assessed through behavioral evaluations. IHC profiles were intact, while the quantities of ribbon synapses and RIBEYE expression showed a trend from increasing to decreasing. These results indicated that the number of ribbon synapses was altered during the development of tinnitus, which might be a type of compensatory mechanism in the early stages of ototoxicity and could contribute to tinnitus later. The alteration of RIBEYE expression could be one possible mechanism underlying the change in the morphology of ribbon synapses as well as salicylate-induced tinnitus. Hence, the mechanism of the change in ribbon synapse structure and function merits further research.

\section{Acknowledgements}

This work is supported by grants from the Natural Science Foundation of China (Nos. 81001029, 81072056 and 30973079), the Ph.D. Programs Foundation of the Ministry of Education of China (Nos. 20102104110009 and 200921041100015$)$ ), and the Foundation of the Educational Department of Liaoning Province (No. L2010564).

\section{References}

1 Cazals Y: Auditory sensori-neural alterations induced by salicylate. Prog Neurobiol 2000;62:583-631.

2 Wilson JP, Sutton GJ: Acoustic correlates of tonal tinnitus. Ciba Found Symp 1981;85:82-107.

3 Roberts LE, Eggermont JJ, Caspary DM, Shore SE, Melcher JR, Kaltenbach JA: Ringing ears: the neuroscience of tinnitus. J Neurosci 2010;30:14972-14979.

4 Turner JG, Parrish J: Gap detection methods for assessing salicylate-induced tinnitus and hyperacusis in rats. Am J Audiol 2008;17:S185-92.

-5 Halla JT, Atchison SL, Hardin JG: Symptomatic salicylate ototoxicity: a useful indicator of serum salicylate concentration? Ann Rheum Dis 1991;50:682-684.

6 Day RO, Graham GG, Bieri D, Brown M, Cairns D, Harris G, Hounsell J, Platt-Hepworth S, Reeve R, Sambrook $\mathrm{PN}$, Smith J: Concentration-response relationships for salicylate-induced ototoxicity in normal volunteers. Br J Clin Pharmacol 1989;28:695-702.

7 Hicks ML, Bacon SP: Effects of aspirin on psychophysical measures of frequency selectivity, two-tone suppression, and growth of masking. J AcoustSoc Am 1999;106:1436-1451.

8 Ruttiger L, Ciuffani J, Zenner HP, Knipper M: A behavioral paradigm to judge acute sodium salicylateinduced sound experience in rats: a new approach for an animal model on tinnitus. Hear Res 2003;180:3950.

-9 Kizawa K, Kitahara T, Horii A, Maekawa C, Kuramasu T, Kawashima T, Nishiike S, Doi K, Inohara H: Behavioral assessment and identification of a molecular marker in a salicylate-induced tinnitus in rats. Neuroscience 2010;165:1323-1332.

10 Lobarinas E, Sun W, Cushing R, Salvi R: A novel behavioral paradigm for assessing tinnitus using scheduleinduced polydipsia avoidance conditioning (SIP-AC). Hear Res 2004;190:109-114.

11 Jastreboff PJ, Brennan JF, Coleman JK, Sasaki CT: Phantom auditory sensation in rats: an animal model for tinnitus. Behav Neurosci 1988;102:811-822. 


\section{Cellular Physiology and Biochemistry}

Cell Physiol Biochem 2014;34:753-767

\begin{tabular}{l|l}
\hline DOI: $10.1159 / 000363040$ & (C) 2014 S. Karger AG, Basel
\end{tabular}

www.karger.com/cpb

Zhang et al.: Ribbon Synaptic Number and RIBEYE Expression in Tinnitus

12 Jung TT, Hwang AL, Miller SK, Rhee CK, Park YS: Effect of leukotriene inhibitor on cochlear blood flow in salicylate ototoxicity. Acta Otolaryngol 1995;115:251-254.

13 Spongr VP, Boettcher FA, Saunders SS, Salvi RJ: Effects of noise and salicylate on hair cell loss in the chinchilla cochlea. Arch Otolaryngol Head Neck 1992;118:157-164.

14 Zheng JL, Gao WQ: Differential damage to auditory neurons and hair cells by ototoxins and neuroprotection by specific neurotrophins in rat cochlear organotypic cultures. Eur J Neurosci 1996;8:1897-1905.

15 Zhang PC, Keleshian AM, Sachs F: Voltage-induced membrane movement. Nature 2001;413:428-432.

16 Kakehata S, Santos-Sacchi J: Effects of salicylate and lanthanides on outer hair cell motility and associated gating charge. J Neurosci 1996;16:4881-4889.

17 Hwang J-H, Chen J-C, Chan Y-C: Effects of C-phycocyanin and Spirulina on salicylate-induced tinnitus, expression of NMDA receptor and inflammatory genes. PLos One 2013;8:e58215.

18 Guitton MJ, Caston J, Ruel J, Johnson RM, Pujol R, Puel JL: Salicylate induces tinnitus through activation of cochlear NMDA receptors. J Neurosci 2003;23:3944-3952.

19 Tan CM, Lecluyse W, McFerran D, Meddis R: Tinnitus and patterns of hearing loss. 2013;14:275-282.

-20 Kimitsuki T, Ohashi M, Umeno Y, Yoshida T, Komune N, Noda T, Komune S: Effect of salicylate on potassium currents in inner hair cells isolated from guinea-pig cochlea. Neurosci Lett 2011;504:28-31.

21 Liu K, Jiang X, Shi C, Shi L, Yang B, Xu Y, Yang W, Yang S: Cochlear Inner Hair Cell Ribbon Synapse is the Primary Target of Ototoxic Aminoglycoside Stimuli. Mol Neurobiol 2013;48:647-654.

22 Zanazzi G, Matthews G: The molecular architecture of ribbon presynaptic terminals. Mol Neurobiol 2009;39: 130-148.

-23 Francis HW, Yeagle JD, Brightwell T, Venick H: Central effects of residual hearing: implications for choice of ear for cochlear implantation. Laryngoscope 2004;114:1747-1752.

24 Nouvian R, Beutner D, Parsons TD, Moser T: Structure and function of the hair cell ribbon synapse. J Membr Biol 2006;209: 153-165.

25 Fuchs PA: Time and intensity coding at the hair cell's ribbon synapse. J Physiol (Lond) 2005;566:7-12.

26 Khimich D, Nouvian R, Pujol R, Dieck ST, Egner A, Gundelfinger ED, Moser T: Hair cell synaptic ribbons are essential for synchronous auditory signalling. Nature 2005;434:889-894.

27 Ruttiger L, Singer W, Panford-Walsh R, Matsumoto M, Lee SC, Zuccotti A, Zimmermann U, Jaumann M, Rohbock K, Xiong H, Knipper M: The reduced cochlear output and the failure to adapt the central auditory response causes tinnitus in noise exposed rats. PLos One 2013;8:e57247.

-28 Singer W, Zuccotti A, Jaumann M, Lee SC, Panford-Walsh R, Xiong H, Zimmermann U, Franz C, Geisler HS, Kopschall I, Rohbock K, Varakina K, Verpoorten S, Reinbothe T, Schimmang T, Ruttiger L, Knipper M: Noise-induced inner hair cell ribbon loss disturbs central arc mobilization: a novel molecular paradigm for understanding tinnitus. Mol Neurobiol 2013;47:261-279.

-29 Schmitz F, Konigstorfer A, Sudhof TC: RIBEYE, a component of synaptic ribbons: a protein's journey through evolution provides insight into synaptic ribbon function. Neuron 2000;28:857-872.

- 30 Zenisek D, Davila V, Wan L, Almers W: Imaging calcium entry sites and ribbon structures in two presynaptic cells. J Neurosci 2003;23:2538-2548.

31 Zheng Y, Lee HS, Smith PF, Darlington CL: Neuronal nitric oxide synthase expression in the cochlear nucleus in a salicylate model of tinnitus. Brain Res 2006;1123:201-206.

- 32 Sheets L, Trapani JG, Mo W, Obholzer N, Nicolson T: Ribeye is required for presynaptic Ca(V)1.3a channel localization and afferent innervation of sensory hair cells. Development 2011;138:1309-1319.

-33 Bauer CA, Brozoski TJ, Rojas R, Boley J, Wyder M: Behavioral model of chronic tinnitus in rats. Otolaryngol Head Neck Surg 1999;121:457-462.

34 Yang G, Lobarinas E, Zhang L, Turner J, Stolzberg D, Salvi R, Sun W: Salicylate induced tinnitus: behavioral measures and neural activity in auditory cortex of awake rats. Hear Res 2007;226:244-253.

-35 Guitton MJ, Pujol R, Puel JL: m-Chlorophenylpiperazine exacerbates perception of salicylate-induced tinnitus in rats. Eur J Neurosci 2005;22:2675-2678.

-36 JAGER BV, ALWAY R: The treatment of acute rheumatic fever with large doses of sodium salicylate; with special reference to dose management and toxic manifestations. Am J Med Sci 1946;211:273-285.

37 Mongan E, Kelly P, Nies K, Porter WW, Paulus HE: Tinnitus as an indication of therapeutic serum salicylate levels. JAMA 1973;226:142-145.

- 38 Halla JT, Hardin JG: Salicylate ototoxicity in patients with rheumatoid arthritis: a controlled study. Ann Rheum Dis 1988;47:134-137. 


\section{Cellular Physiology Cell Physiol Biochem 2014;34:753-767 \\ and Biochemistry \begin{tabular}{l|l} 
DOI: 10.1159/000363040 & O 2014 S. Karger AG, \\
Publisned onIIne: August 19, 2014 & www.karger.com/cpb
\end{tabular}}

Zhang et al.: Ribbon Synaptic Number and RIBEYE Expression in Tinnitus

-39 Liu J, Li X, Wang L, Dong Y, Han H, Liu G: Effects of salicylate on serotoninergic activities in rat inferior colliculus and auditory cortex. Hear Res 2003;175:45-53.

40 Mahlke C, Wallhausser-Franke E: Evidence for tinnitus-related plasticity in the auditory and limbic system, demonstrated by arg3.1 and c-fos immunocytochemistry. Hear Res 2004;195:17-34.

41 Chen GD, Kermany MH, D'Elia A, Ralli M, Tanaka C, Bielefeld EC, Ding D, Henderson D, Salvi R: Too much of a good thing: long-term treatment with salicylate strengthens outer hair cell function but impairs auditory neural activity. Hear Res 2010;265:63-69.

42 Su YY, Luo B, Jin Y, Wu SH, Lobarinas E, Salvi RJ, Chen L: Altered neuronal intrinsic properties and reduced synaptic transmission of the rat's medial geniculate body in salicylate-induced tinnitus. 2012;7:e46969.

43 Berger JI, Coomber B, Shackleton TM, Palmer AR, Wallace MN: A novel behavioural approach to detecting tinnitus in the guinea pig. J Neurosci Methods 2013;213:188-195.

-44 Boettcher FA, Salvi RJ: Salicylate ototoxicity: review and synthesis. Am J Otolaryngol 1991;12:33-47.

45 Chen L, Xiong S, Liu Y, Shang X: Effect of Different Gentamicin Dose on the Plasticity of the Ribbon Synapses in Cochlear Inner Hair Cells of C57BL/6J Mice Mol Neurobiol 2012;46:487-494.

46 Dieler R, Shehata-Dieler WE, Brownell WE: Concomitant salicylate-induced alterations of outer hair cell subsurface cisternae and electromotility. J Neurocytol 1991;20:637-653. 